\title{
Localization of Sugar Residues in the Stomach of Three Species of Monkeys (Tupaiidae glis, Nycticebus cocang and Callithrix jacchus) by Lectin Histochemistry
}

\author{
Localización de los Residuos de Azúcar en el Estómago de Tres Especies de Monos \\ (Tupaiidae glis, Nycticebus cocang y Callithrix jacchus) por Histoquímica de Lectina
}

"Masoud Hassan Fayed; "**Mohamed Elnasharty \& ${ }^{* * *}$ Mahmoud Shoaib

FAYED, M. H.; ELNASHARTY, M. \& SHOAIB, M. Localization of sugar residues in the stomach of three species of monkeys (Tupaiidae glis, Nycticebus cocang and Callithrix jacchus) by lectin histochemistry. Int. J. Morphol., 28(1):111-120, 2010.

SUMMARY: The stomach of three species of non-human primates was investigated by lectin histochemistry to clarify the staining affinity and distribution patterns of their sugar residues. All gastric regions, with little differences between the deep and superficial parts of the same region, were rich in. in $\mathrm{N}$-acetylglucosamine and/or neuraminic acid. Although, the superficial regions of the gastric mucosa were scanty in $\mathrm{N}$-acetylgalactosamine, a- D-glucose and a -D-mannose, the deep parts of the gastric mucosa were rich in these sugars. In conclusion, there is a difference among the mucosubstances of surface and foveolar mucous cells, mucous neck cells, and gastric gland cells. This indicates heterogeneous composition of gastric mucus, or mucus molecules with variations in the degree of glycosylation of their oligosaccharide chains in the different cells which suggest that lectin binding affinity in the gastric mucosa correlated mostly to the degree of cellular differentiation.

KEY WORDS: Histochemistry; Lectins; Non-human primates; Stomach.

\section{INTRODUCTION}

Non human primates present a unique animal model for human disease because of their phylogenetic closeness to human, their convenient size, rather than omnivorous nature of diet and their ability to stay healthy in captivity. Previous investigations showed that, the oligosaccharides side chain of the complex carbohydrate in numerous mammalian glycoconjugates terminates with different sugar residues (Kornfed \& Kornfed, 1976; Horowitz \& Pigman, 1977; Montereuil, 1980). Those of the gastrointestinal tract are composed of four sugars, galactos (Gal), Nacetylgalactosamine (GalNAc), N-acetylglucosamine (GlcNAc) and a-L-Fucose (a-L-Fuc) present in very constant molecular ratio (Allen \& Snary, 1972; Clamp et al., 1981 and Forster et al., 1982). These sugars play a key role in the normal functions of these glycoconjugates. Such function includes regulation of protein conformation, protection of protein from proteolytic attack, cell-cell interaction
(Montereuil), and ion transport across the membrane (Vandeheede et al., 1972). These sugars have been histochemically localized in the mucus secreting cells of human (Aoki et al., 1993), carnivorous (Mayer \& Tsukise, 1995), camel (Fayed \& Makita, 1997), in rates (Tatematsu et. al., 1989), in fish (Pedini, et al., 2005) and in experemintal animals (Ishihara et al., 1996; Yang et al., 1996). Recent lectin-histochemical investigations have shown that several lectins are able to label gastrointestinal mucus secreting cells selectively besides the distribution and characterization of their glycoconjugates (Watanabe et al., 1981; Fischer et al., 1984a; Madrid et al., 1989). In pursuit of characterization of lectin binding patterns in normal monkey gastric mucosa, we have systematically studied the distribution of the sugar residues and their suggested biology in the monkey gastric mucosa using lectins as a probe and horseraddish peroxidase (HRP) as visualant.

* Department of Anatomy, Faculty of Veterinary Medicine, Kafr El-Sheikh University, Egypt.

** Department of Cytology and Histology, Faculty of Veterinary Medicine, Mansoura University, Egypt.

${ }^{*}$ Department of Anatomy and Embryology, Faculty of Veterinary Medicine, Mansoura University, Egypt. 


\section{MATERIAL AND METHOD}

Animals. The samples were collected from three species of non-human primates, monkeys, obtained from department of Anatomy, united graduated school of Veterinary Medicine, Yamaguchi University, Yamaguchi, Japan. All investigations were completed in the department of Anatomy and Histology, Faculty of Veterinary Medicine, Kafer ElSheikh University, Egypt. A total of nine animals were used for this experiment. Amoung these animals, three were of common treeshrew monkeys (Tupaiidae glis), three were of slow rolis monkeys (Nycticebus cocang) and three of common marmost monkeys (Callithrix jac-chus).

Sample collection and tissues preparation. The approval of the protocol for this research project has been previously arranged by professor Dr. Makita, T. (info@afvt.jp) and so the strict animal welfare regulations and the rules of the animal ethics committee in Japan were followed.

The monkeys were sacrified under deep anaesthesia with an intravenous injection of pentobarbital sodium (50 $\mathrm{mg} / \mathrm{kg}$ ). The samples were rapidly removed and pieces of its tissue were fixed in phosphate buffer saline (PBS) contain 4\% paraformaldehyde for 72 hours and thoroughly rinsed in the same buffer. A total of 10 sections of $4 \mathrm{~mm}$ thickness from each gastric regions for each histochemical procedures were examined. The section were deparafinized in xylene and deyderated in gradual ethanole series. One section from each gastric regions stained with Gill's hematoxylen (Gill et al., 1974) and eosin (H \& E) for general histological assessment. The other 9 sections were subjected to the histochemical staining procedures summarized in Table I. for detection of the binding sites of the sugar residues.

HRP Lectin technique. The processing and staining procedure with the various lectins (Table I) was similar to that described by Schulte \& Spicer (1983), Bancroft \& Stevenes (1996) and Rhodes \& Milton (1998). Briefly, after hydration the sections were treated with $0.3 \%$ hydrogen peroxide $\left(\mathrm{H}_{2} \mathrm{O}_{2}\right)$, rinsed in distilled water and washed in $1 \%$ bovine serum albumen (BSA) in 0.1M PBS pH 7.4. The sections were incubated for 12 hours at $4{ }^{\circ} \mathrm{C}$ in HRP-lectin (Sigma Chemical Co. St. Louis, Mo, USA), dissolved in 0.1M PBS pH 7.4 (contains 0.1 M NaCL2, 0.1 $\mathrm{mM} \mathrm{CaCL}_{2}$, $\mathrm{MgCl}_{2}$, and $\mathrm{MnCL}_{2}$ ) and then rinsed three times in PBS. The optimal concentration used with each lectin which allowed maximum staining with mininum background was as listed in Table I. Visualization of the sites containing HRPlectin was obtained by incubating the slides with PBS containing 3', 3' diaminobenzidine tetrahydrochloride (DAB) (25 mg/100 ml and $0.003 \% \mathrm{H}_{2} \mathrm{O}_{2}$ ) for $10 \mathrm{~min}$, at room temperature. Slides were rinsed in distilled water, dehydrated using gradual ethanol solutions, cleared in xylene and mounted in DPX.

Hapten sugars inhibition. Every lectins was preincubated with the corresponding hapten sugars listed in Table I. The hapten sugar inhibitors were employed from $0.05 \mathrm{M}$ to $1 \mathrm{M}$ and complete elimination of the staining was obtained at $0.2 \mathrm{M}$.

\section{RESULTS}

Histological Observations. Using the light microscope, the results of the current investigation were similar in the three examined species of monkey either in general histological assissment or lectin histochemistry and no significant differences could be noticed between them. In histological sections, the gastric mucosa appeared lined by a simple columnar epithelium that invaginated to form the gastric pits which were continuous with the gastric glands and received their secretory products. The gastric wall contained aggregated lymphoid nodules at the cardiac region distributed as a band-like region along the cardio-esophageal junction (Fig. 1a and b) in the submucosa however; few of them were located in the deep layer of the mucosa, lamina

Table (1): Carbohydrate binding specificity of lectins used in this study.

\begin{tabular}{lcccccc}
\hline Taxonomic name & $\begin{array}{c}\text { Common } \\
\text { name }\end{array}$ & $\begin{array}{c}\text { Abbreviation } \\
\mathrm{s}\end{array}$ & Label & $\begin{array}{c}\text { Concentration } \\
\mu \mathrm{g} / \mathrm{ml}\end{array}$ & $\begin{array}{c}\text { Major sugar } \\
\text { specification }\end{array}$ & Sugar binding inhibitor \\
\hline Arachis hypogea & Peanut & PNA & HRP & 100 & Gal-B-(1-3)-GaLNAc & Gal \\
Canavalia ensiformis & Jake bean & Con-A & HRP & 20 & - D-Man, _-D-Glc & - methyl-D-Man \\
Triticum vulgaris & Wheat germ & WGA & HRP & 6 & GlcNAc)2,NeuNAc & NeuNAc \\
\hline
\end{tabular}

Symbol: Gal=Galactose; Glc=Glucose; GalNAc=N-acetylgalactosamine; GlcNAc= N-acetylglusoamine; Man=Mannose; NeuNAc=N-acetyl neuraminic acid (sialic acid); HRP = horseradish peroxidas 
propria in between the gastric glands. The mucosal folds were broader in these regions than where there were no aggregated lymphoid nodules. The cardiac glands characterized by shallow gastric pits and short simple coiled tubular glands extended in the lamina propria that contained little amount of connective tissue filling the space in between the glands. The fundic gland region showed long straight glands with shallow gastric pits. The fundic glands filled the lamina propria almost completely with very little amount of connective tissue in between them (Fig. 1c and d). Besides the surface mucous secreting cells and the mucous neck cells, the main two cells observed in the fundic glands were the chief and parietal cells. The pyloric glands were similar to cardiac glands except that, their gastric pits were markedly deep and there were no lymphoid nodules any where in this region.
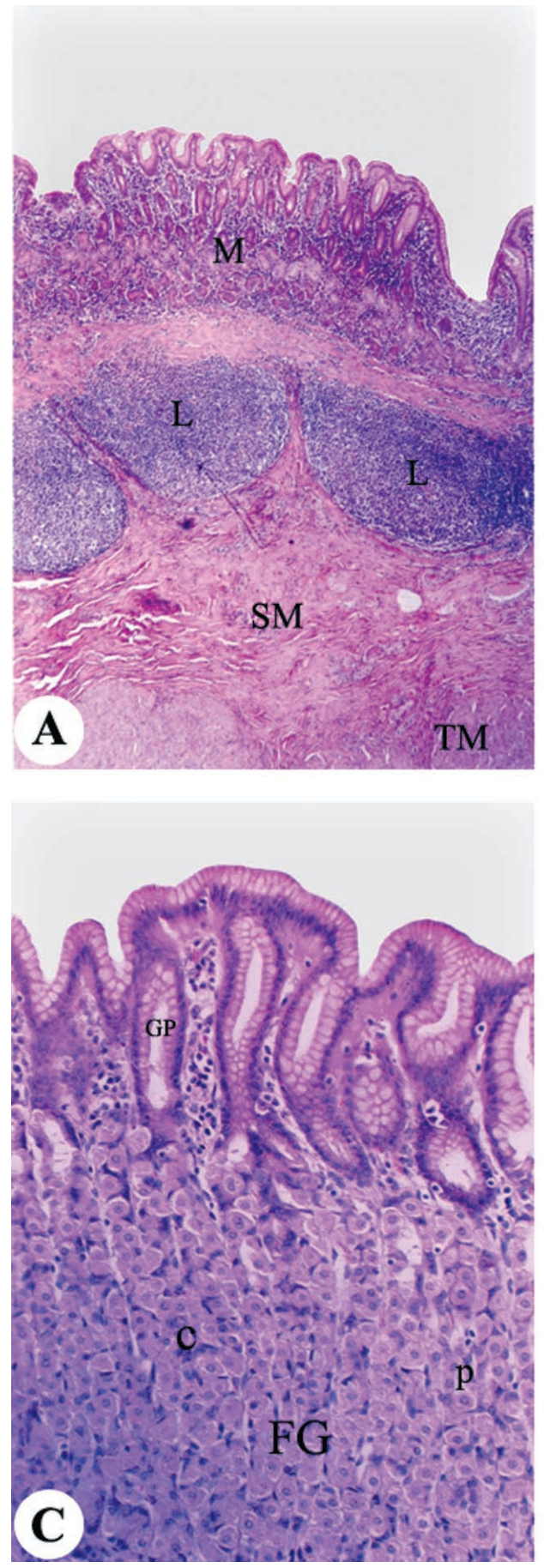
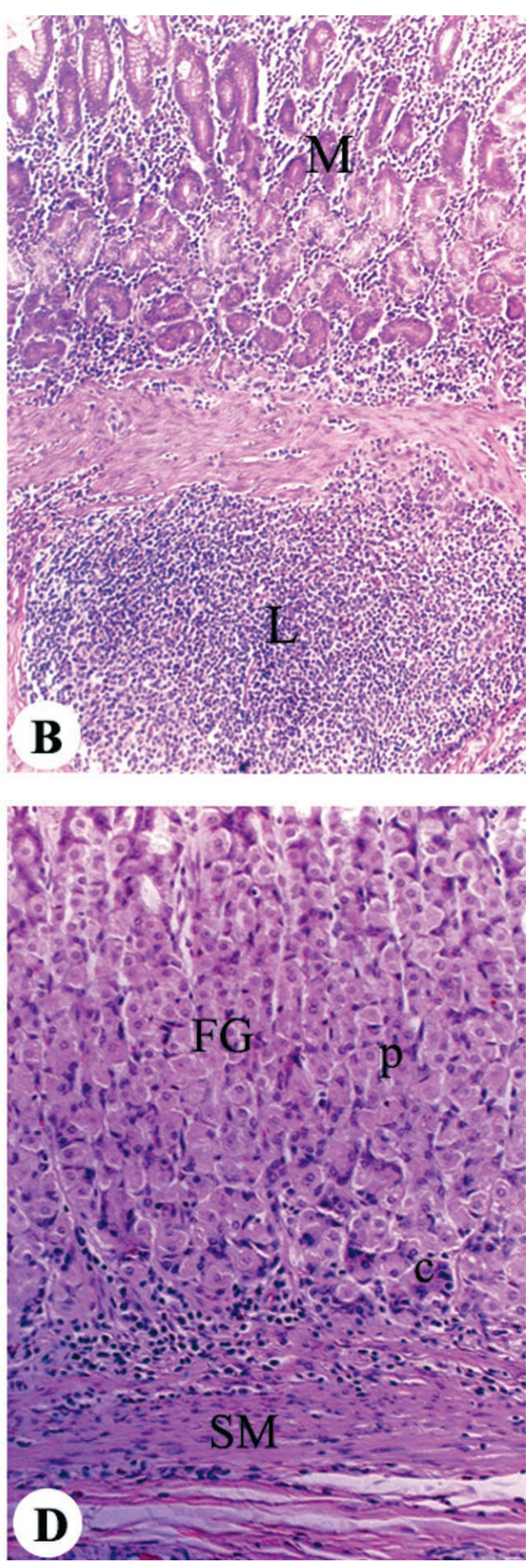

Fig.1. The gastric mucosa at the cardiac and fundic gland regions. A; low power of the gastric wall at the cardiac region showing the mucosa (M), submucosa $(\mathrm{SM})$ containing the lymphoid nodules (L) and the tunica muscularis (TM). Note the broad mucosal fold at the region of lymphoid nodules. B; higher magnification to the same region showing the mucosa (M) and the lymphoid nodules in the submucosa (L). $\mathrm{C}$; higher magnification to the fundic glands showing the shallow gastric pits (GP) and the long straight fundic glands (FG) with its chief cells (C) and parietal cells (P). D: higher magnification to the fundic glands (FG) and its chief cells (C) and parietal cells (P); SM, sub mucosa. $\mathrm{H} \& \mathrm{E}$ stain. $\mathrm{Bar}=$ $100 \mathrm{~mm}$ in $\mathrm{A}, \mathrm{B}$ and $\mathrm{C}$. 
Histochemical Observations. Marked differences in the staining pattern with lectin conjugates used in the current study could be noticed, not only between the different gastric regions but also among the various microanatomical structures of the same region particularly between the base, middle and upper parts of the gastric glands.

The cardiac gland region showed strong positive reaction to HRP-conjugated Triticum vulgaris agglutinine
(HRP/WGA). This positive reaction included the surface mucous cells, the gastric pits and the gastric glands (Fig. 2). At the beginning of the cardiac gland region, antral region, the glands showed positive reaction along their whole length even in the portions surrounded the lymphoid nodules located at this region (Fig. 2c). Later on, while directing backward, the positive reaction disappeared from the base of the glands and restricted to the surface mucous cells and the upper
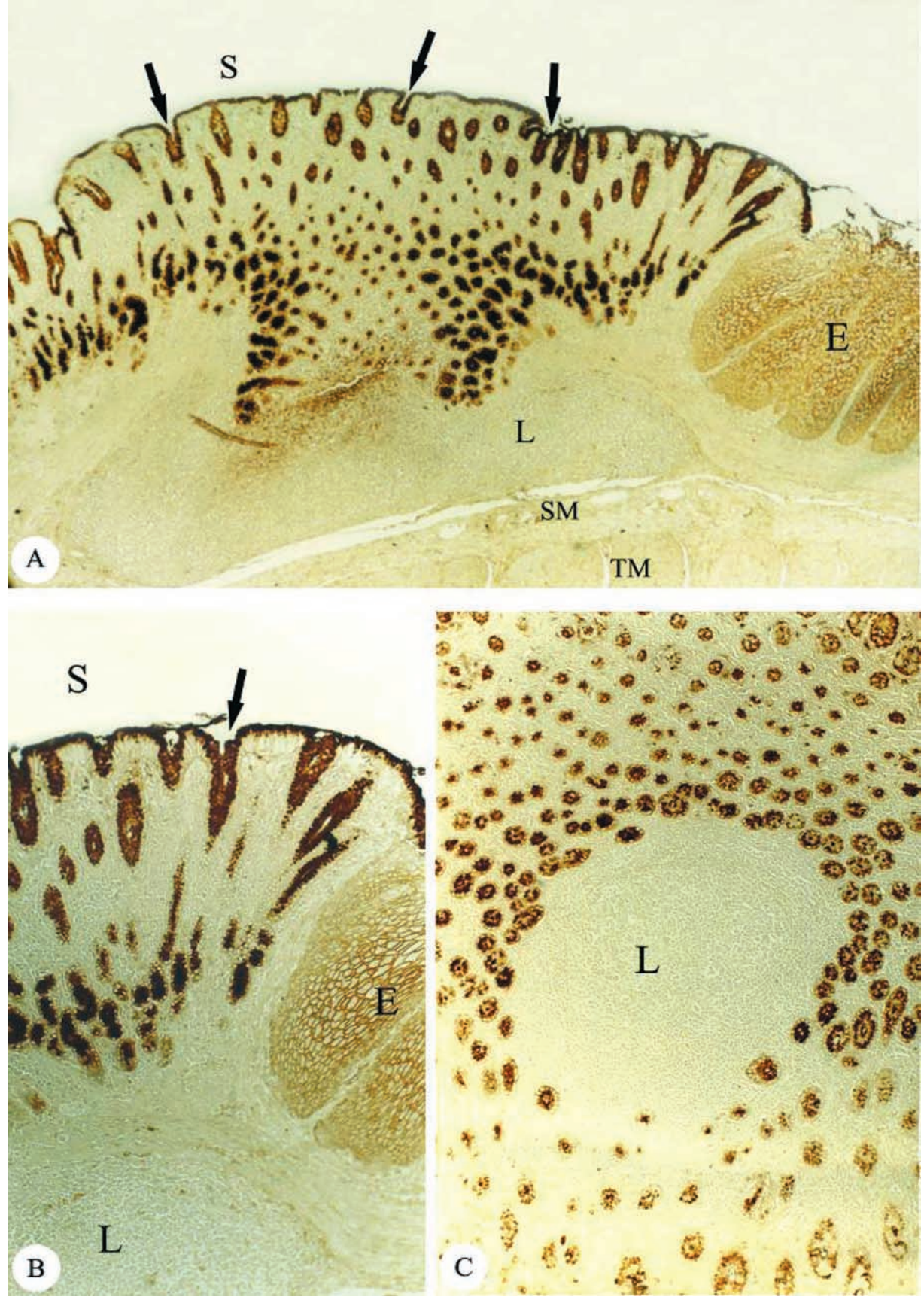

Fig. 2. Cardio-esophageal junction of monkey stomach stained by HRP/WGA lectin histochemistry. A; is a low power magnification to the junction showing the strong positive reaction to these lectins in the surface mucous cells (S), the gastric pits (arrows) in the cardiac glands; L, lymphoid nodules, SM, submucosa, TM, tunica muscularis, and $\mathrm{E}$, esophageal epithelium. B; higher magnification to the junction, S, surface mucous cells, arrow, gastric pits, L, lymphoid nodules, E, esophageal epithelium. $\mathrm{C}$; is a higher magnification to the deep layer of cardiac glands showing lymphoid nodules (L) may extend to the lamina propria and surrounded by the positively stained cardiac glands. Bar $=100$ $\mathrm{mm}$ in $\mathrm{A}, \mathrm{B}$ and $\mathrm{C}$. 

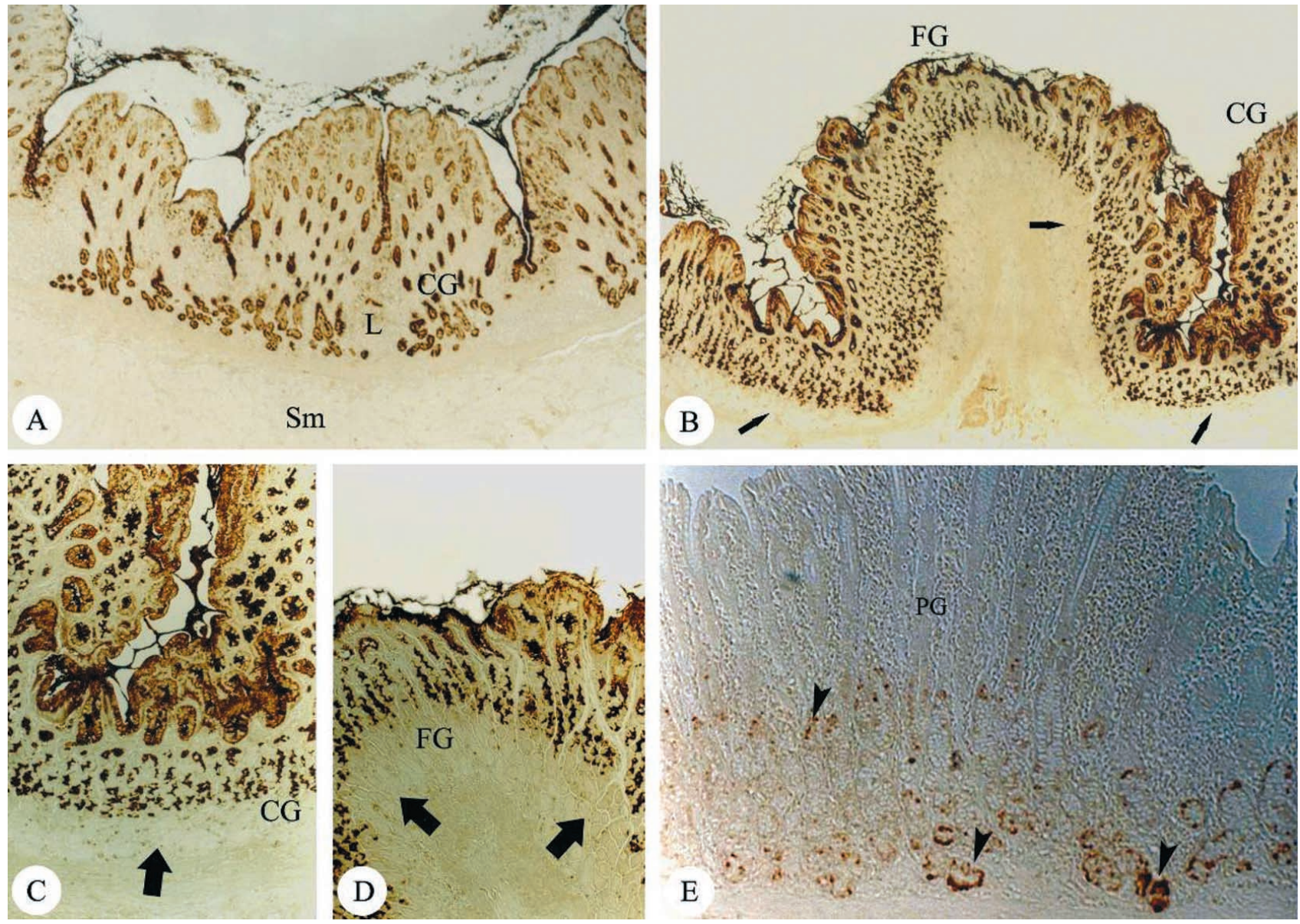

Fig. 3. Different regions of the stomach of monkey stained by the HRP/WGA lectin histochemistry. A; Low power to the cardiac gland region $(\mathrm{CG})$ showing the positive reaction in the entire length of the glands; Sm, submucosa. Note also the strong positive reaction in the mucus covering the gastric mucosa. B; Transition zone between the cardiac gland (CG) and the fundic gland (FG). Note here the base of the glands in both regions is negative (arrows). C and D; Higher magnifications to the cardiac gland (CG) and fundic glands (FG) respectively, showing the negative reaction at the bases of the gastric glands (broad arrows). E; Pyloric gland region (PG) showing the positive reaction in some cells of the lower part of the glands only (arrow heads). Bar $=100 \mathrm{~mm}$ in A, B, C, D and E.

portions of the cardiac glands, isthmus and body regions (Fig. 3). A similar distribution of HRP/WGA lectin binding sites was seen in the fundic gland region, where the positive reaction was limited to the upper portion of the glands and disappeared from their bases. The opposite pattern of staining was noticed in the pyloric gland region. The surface mucous cells and the gastric pits were negative while some cells in the bodies and the bases of the glands were moderately stained (Fig. 3e). The secreted mucous, covering the gastric mucosa, was strongly positive to HRP/WGA in the cardiac and fundic gland regions and negative in the pyloric gland region.

The results obtained by HRP-conjugated / Concanavalia ensiforms agglutinine (HRP/Con-A) in the cardiac gland and pyloric gland regions were similar. In the both regions, the surface mucous epithelium and the foveolar epithelium showed negative reaction, while the bodies and the bases of the glands gave a strong positive reaction to HRP/Con-A. In the cardiac gland region, the positive reaction extended to the region surrounding the lymphatic nodules (Fig. 4). Almost similar reaction could be noticed in the fundic gland region, where the surface mucous cells and the foveolar cells were negative, the bases of the glands showed negative reaction too. The body of the fundic gland was the only part with positive reaction with HRP/Con-A.

Similar results could be noticed in the staining affinity of different regions of gastric mucosa in case of HRPconjugated Peanut agglutinine (HRP/PNA). In the pyloric gland region, strong positive reaction was noticed in some cells at the base of the glands only, while the surface mucus cells, cells lining the foveolae and the body of the pyloric glands showed negative reaction (Fig. 5). 

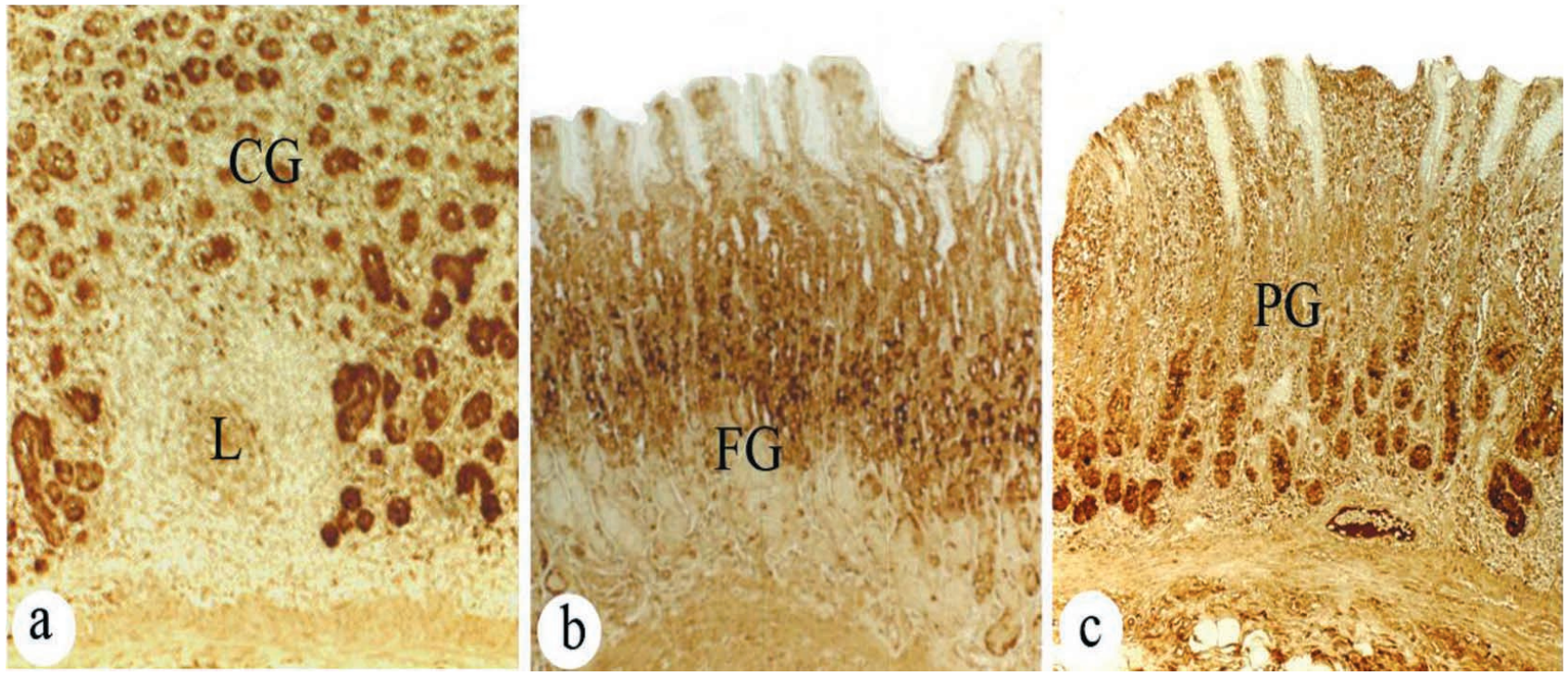

Fig. 4. The HRP/Con-A lectins histochemistry in the cardiac (CG) in a; in fundic (FG) in b; and in pyloric glands (PG) in c. Note that the positive reaction at the cardiac gland region extended to the deep layer of the glands even in the portions surrounded the lymphoid nodules $(\mathrm{L})$. At the fundic gland the positive reaction was limited to the body region while the positive reaction at the pyloric gland region located in the body and base of the glands with no reaction in the surface mucous cells and the gastric pits. Bar $=100 \mathrm{~mm}$.

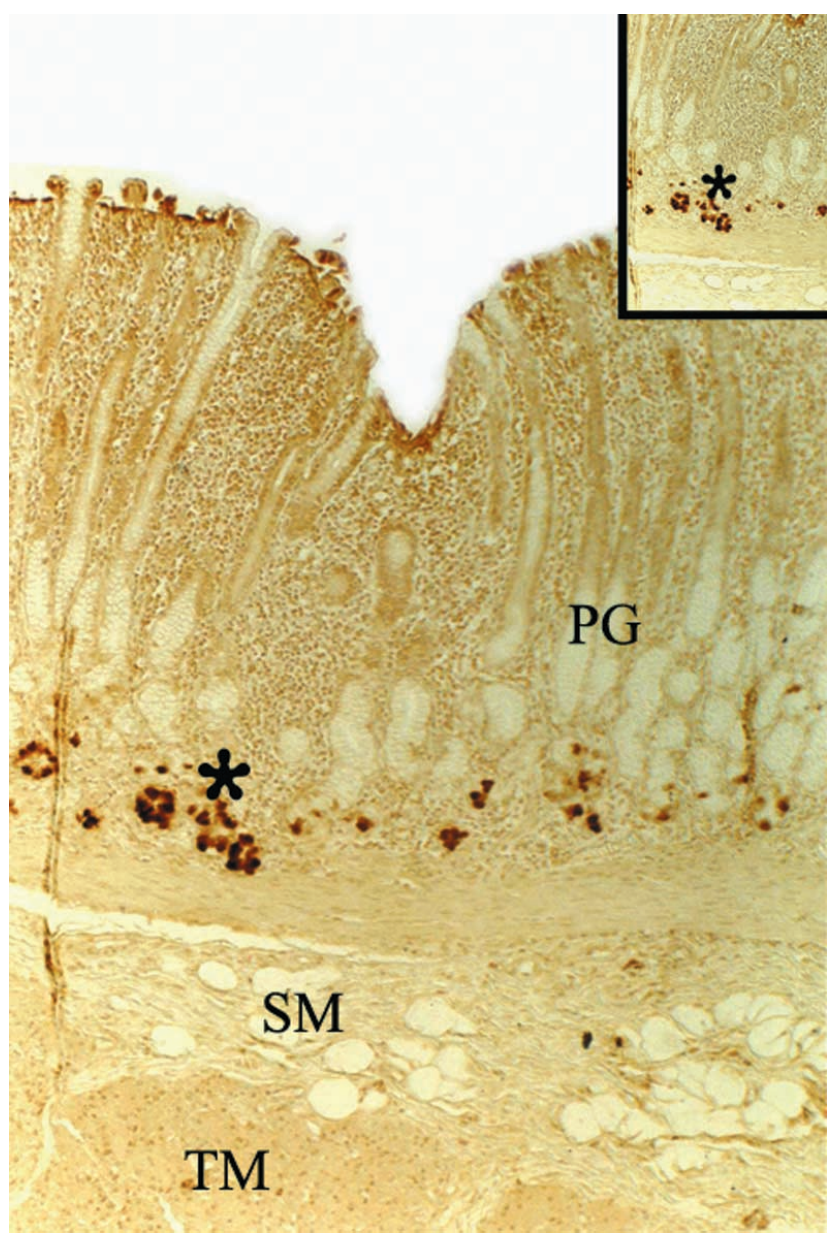

\section{DISCUSSION}

The current study revealed that there was an aggregated lymphoid nodule in the gastric wall especially at the cardiac region. In an agreement with this result Wang (2003) reported lymphoid nodules distributed as a band like region along the ventral wall of the stomach neck of Bactrian camel. These findings indicate that the stomach of monkey possesses not only a special structure of digestion but also has characteristic immunological morphology and these aggregated lymphoid nodules are an important part of the gutassociated lymphoid tissue.

In the stomach, the mucus plays a key role in the defense mechnism of gastric epithelial cells from the corrosive hydrochloric acid and from pepsin of the gastric juice (Ferri \& Liquori, 1992). The composition of the mucins of the digestive tract probably depends on their functions. This microheterogeneity of the mucins as revealed by lectin histochemistry can be attributed to the ability of the mucus to

Fig. 5. Pyloric gland region of monkey stomach stained by the HRP/ PNA lectins histochemistry at the $(\mathrm{PG})$ showing the negative reaction in the surface mucous cells, in gastric pits and body of the glands. The only positive reactions found in some cells at the bases of the glands (asterisk). Inset; is a higher magnification to the region at the gland bases showing the positive reaction. Bar $=100 \mathrm{~mm}$ for the figure and inset. 
entrap a wide variety of microorganisms. Despite the carbohydrate microheterogeneity, the mucins of various origins are very similar in their macromolecular properties and polymeric structure (Madrid et al., 1998).

The results of our study have shown regional and cellular differences in carbohydrate components of the gastric mucosa and have demonstrated the selectivity and the reliability of individual lectins. Similar results concerning the different pattern of lectin binding sites have been reported by many authors (Spicer et al., 1978; Stoward et al., 1980; Suzuki et al., 1982; Kuhlmann et al., 1983; Fischer et al., 1983; Fischer et al., 1984a; Fischer et al., 1984b; Madrid et al., 1990; Ferri \& Liquori; Rios-Martin et al., 1993; Jiang et al., 2004; Schumacher et al., 2004).

In the current study, the staining affinity of gastric mucosa to the WGA was strong at the cardio-esophageal junction in the gastric surface mucous epithelial, mucous neck cells and cardiac glands. Then after, this affinity was confined to the surface mucous cell and the foveolar mucous cells in the cardiac and fundic glands. In the pyloric gland region this affinity was restricted to the body and base of the glands while it was absent from both the surface mucous cell, and foveolar mucous cells. The mucous covering of the gastric mucosa was positive in both cardiac and fundic gland regions and negative in the pyloric gland region. In this context Ito et al. (1985) mentioned that the mucous neck cells produce acidic mucins that bind WGA. Madrid et al. (1990) reported that the mucinous content of the cells lining the surface and pit of gastric mucosa as well as mucous neck cells were moderately reactive to WGA. Rios-Martin et al. documented that extracellular mucus was negative for WGA. Fischer et al. (1984a) mentioned that WGA binds to gastric mucus secreting cells. In contrast to our results, Suzuki et al. mentioned that the mucous granules of the pyloric gland cells and mucous neck cells showed an affinity for WGA as well as surface and foveolar mucous cells bind to WGA. The intense reaction of gastric mucosa to WGA sugest the presence of N-acetyl-Dglucosamine (GlcNac) and $\mathrm{N}$-acetyl neuraminic acid residues (Ishida et al., 1988; Bogoeva et al., 2004). The presence of neuraminic acid in gastric mucosa and mucous is important for entraping a wide variety of microorganisms; defensive function (Madrid et al., 1998).

Our results indicated that the cardiac gland region showed a positive reaction to the Con-A in the deep portions of the glands even in the portions surrounded the lymphoid nodules, while the surface mucous and foveolar epithelium were negative. The same result could be noticed in the pyloric glands, where the surface mucous epithelium and the foveolar epithelium showed negative reaction, the body and the bases of the glands showed a strong positive reaction. Similarly,
Suzuki et al. documented that the mucous granules of the pyloric gland cells and mucous neck cells showed an affinity for Con-A, while surface and foveolar mucous cells do not bind to Con-A. These results clearly show the difference among the mucosubstances of mucous neck cells, pyloric gland cells, and surface and foveolar mucous cells. The mucosubstances of the mucous neck cells and pyloric glands cells contain ConA binding sugar residues, a-D-glucos and a-D-mannos, whereas the mucosubstances of the surface and foveolar mucous cells contain little or none. This sugested that the gastric mucosubstances contain either small amount of mannose or none.

In an accordance Ito et al. and Madrid et al. (1990), mentioned that the mucous neck cells produce acidic mucins that bind mostly with Con-A. In the same time, Ito et al. reported that in human gastric mucosa, the secretory granules of the surface mucous cells showed negative reaction with Con-A. In addition, Fischer et al. (1984a), documented that the mucus in the surface mucous cells of gastric mucosa was characterized by the absence of Con-A binding sites, while all cell types lying under the proliferation zone are intensely stained. Similar results could be observed in camel stomach (Fayed \& Makita).

We reported here that the gastric mucosa showed various patterns of staining with the PNA. The positive reaction was limited to some cells at the bases of the pyloric glands with negative reaction in the surface mucous cells and in foveolar mucous cells. In contrast, Ito et al. reported that in human gastric mucosa, the secretory granules of the superficial mucous cells reveal specific binding with PNA and the mucous neck cells produce acidic mucins that bind PNA. Kuhlmann et al. mentioned that large numbers of surface mucous cell, neck and cardiac gland cells stained with PNA. Moreover, Rios-Martin et al. documented that labeling with PNA revealed a biphasic pattern (peripheral positively) on mucous droplets in surface and foveolar cells.

In an accord, Fischer et al. (1984a) mentioned that the mucus in the surface epithelial cells of gastric mucosa was characterized by the absence of PNA reaction. They added, mucous neck cells and some antral gland showed a high density of PNA lectin binding, while those of deep foveolar and isthmus cells showed moderate reaction to PNA. In addition, Stoward et al. found that cardiac glands and mucous neck cells, in the deep but not the superficial portion, of gastric glands stained strongly with PNA. According to McCartney (1986), binding of PNA to surface mucous cells of gastric mucosa occurred in non-secretors but not secretors. The absence of PNA binding sites from the gastric surface epithelium sugested that it is apparently possessed neither terminal galactose residues nor galactose-sialic acid dimmers (Fischer et al., 1984a). 
The different binding of labeled lectins to the individual cell types of the normal mucosa sugest differences in glycoprotein composition of the: a) surface epithelial cells showing various degrees of differentiation; $b$ ) cell types lying above and below the generative cell zone; c) specific membrane systems of the parietal and chief cells (Fischer $e t$ al., 1983). Moreover, the variation in lectin binding sites between the different cell types is an indicative to a reduced glycosylation in mucous neck cells and other glandular epithelial cells in comparison with surface mucous cells (Fischer et al., 1984a).

In conclusion our findings suggest that there is a difference among the mucosubstances of surface and foveolar mucous cells, mucous neck cells, and gastric gland cells, i.e. heterogeneous composition of gastric mucus, or mucus molecules with variations in the degree of glycosylation of their oligosaccharide chains in the different cells. Besides, lectin binding patterns in gastric mucosa are related, most likely, to the degree of cellular differentiation.

\section{ACKNOWLEDGMENTS}

We are gratefully thanks professor Dr. Makita, T. (info@afvt.jp) previously the dean of faculty of agriculture, Yamaghi University, Yamaghi, Japan for his critical reading of the manuscripts and kind supplement of the original samples.

FAYED, M. H.; ELNASHARTY, M. \& SHOAIB, M. Localización de los residuos de azúcar en el estómago de tres especies de monos (Glis Tupaiidae, cocang Nycticebus y Callithrix jacchus) por histoquímica de lectina. Int. J. Morphol., 28(1):111-120, 2010.

RESUMEN: El estómago de tres especies de primates no humanos fue investigado por histoquímica de lectinas para determinar la afinidad de tinción y los patrones de distribución de sus residuos de azúcar. Todas las regiones gástricas, con pequeñas diferencias entre las partes profundas y superficiales de la misma región, eran ricas en $\mathrm{N}$-acetilglucosamina y/o ácido neuramínico. Si bien, las regiones superficiales de la mucosa gástrica eran escasas en $\mathrm{N}$-acetilgalactosamina, a-D-glucosa y a-D-manosa, las partes profundas de la mucosa gástrica eran ricas en estos azúcares. En conclusión, existe una diferencia entre las mucosustancias de la superficie y células mucosas foveolares, células mucosas del cuello y células de las glándulas gástricas. Esto indica una composición heterogénea de la mucosa gástrica, o moléculas de moco con variaciones en el grado de glicosilación de sus cadenas de oligosacáridos en las diferentes células, sugieriendo que la afinidad de union de lectinas en la mucosa gástrica se relacionada principalmente con el grado de diferenciación celular.

PALABRAS CLAVE: Histoquímica; Lectinas; Primates no humanos; Estómago.

\section{REFERENCES}

Allen, A. \& Snary D. The structure and function of gastric mucous. Gut, 13:666-72, 1972.

Aoki, T.; Kawano, J.; Oinuma, T.; Haraguchi, T.; Eto, T. \& Suganuma, T. Human colorectal carcinoma glycoconjugates detected by pokeweed mitogen lectin. J. Histochem. Cytochem, 41(9):1321-30, 1993.

Bancroft, J. \& Stevens, A. Theory and Practice of Histological Techniques. London, Churchill Livingestone, 1996.

Bogoeva, V.; Radeva, M.; Atanasova, L.; Stoitsova, S. \& Boteva, R. Fluorescence analysis of hormone binding activities of wheat germ agglutinin. Biochem. Biophys. Acta., 1698(2):213-8, 2004.

Clamp, J. R.; Fraser, G. \& Reid, A. E. Study of the carbohydrate content of mucous glycoprotein from normal and diseased colons. Clin. Sci., 61:229-34, 1981.
Fayed, M. \& Makita, T. Lectin histochemistry of the glandular part of the gastric mucosa of the one humped camel (Camelus dromedarius). Acta. Histochem. Cytochem., 30:423-31, 1997.

Ferri, D. \& Liquori, G. E. Characterization of secretory cell glycoconjugates in alimentary tract of ruin lizard (Podarcis sicula campestris DE BETTA) by means of lectin histochemistry. Acta. Histochem., 93(1):341-49, 1992.

Fischer, J.; Klein, P. J.; Vierbuchen, M.; Fischer, R. \& Uhlenbruck, G. Lectin binding properties of glycoprotein in cells of normal gastric mucosa and gastric cancers: A comparative histochemical and biochemical study. Cancer Detect. Prev., 6(1-2):137-47. 1983.

Fischer, J.; Klein, P. J.; Vierbuchen, M.; Skutta, B.; Uhlenbruck, G. \& Fischer R. Characterization of glycoconjugates of human gastrointestinal mucosa by lectins. I. Histochemical distribution of lectin binding 
sites in normal alimentary tract as well as in benign and malignant gastric neoplasm. J. Histochem. Cytochem., 32(7):681-9, 1984a.

Fischer, J.; Uhlenbruck, G.; Klein, P.; Vierbuchen, M. \& Fischer. R. Characterization of glycoconjugates of human gastrointestinal mucosa by lectins. II. Lectin binding to the isolated glycoprotein of normal and malignant gastric mucosa. J. Histochem. Cytochem., 32(7):690-6, 1984b.

Forster, G.; Wesley, A. \& Forster, J. Mucous in health and disease. New York, Plenum Press, 1982. pp.199-224.

Gill, G. W.; Frost, J. K. \& Miller, K. A. A new formula for half oxidized hematoxylin solutions that neither over stain nor require differentiation. Acta. Cytol., 18(4):300$11,1974$.

Horowitz, M. \& Pigman, W. The glycoconjugates. New York, Academic Press, 1977.

Ishihara, K.; Kurihara, M.; Goto, Y.; Ota, H.; Katsuyama, T. \& Hotta, K. Establishment of monoclonal antibody against gastric mucins distributed in the different sites of and layer of the gastric mucosa. Glycoconj. J., 13(5):857-64, 1996.

Ishida, K.; Suganuma, T.; Tsuyama, S. \& Murata, F. Glycoconjugate histochemistry of the rat fundic gland using Griffonia simplicifolia agglutinin-II during the development. Am. J. Anat., 182(3):250-6, 1988.

Ito, M.; Takata, K.; Saito, S.; Aoyagi, T. \& Hirano H. Lectinbinding pattern in normal human gastric mucosa. A light microscopic study. Histochem., 83(3):189-93, 1985.

Jiang, C.; McClure, S.; Stoddart, R. \& McClure, J. Lectin histochemistry of normal human gastric mucosa. Glycoconj. J., 20(6):367-74, 2004.

Kornfed, R. \& Kornfed, S. Comparative aspects of glycoprotein. Annu. Rev. Biochem, 45:217- 24, 1976.

Kuhlmann, W. D.; Peschke, P. \& Wurster, K. Lectinperoxidase conjugates in histopathology of gastrointestinal mucosa. Virchows Arch. A Pathol. Anat. Histopathol., 398(3):319-28, 1983.

MaCartney, J. Lectin histochemistry of galactose and Nacetyl-galactosamine glycoconjugates in normal gastric mucosa and gastric cancer and the relationship with $\mathrm{ABO}$ and secretor status. J. Pathol., 150(2):135-44, 1986.
Madrid, J.; Ballesta, J.; Castells, M. \& Hernández F. Glycoconjugate distribution in the human fundic mucosa revealed by lectin-and glycoprotein-gold cytochemistry. Histochem., 95(2):179-87, 1990.

Madrid, J.; Ballesta, J.; Castells, M.; Marin, J. \& Pastor, L. Characterization of the glycoconjugates in the intestinal mucosa of vertebrates by means of lectin histochemistry. Acta Histochem. Cytochem., 22:1-12, 1989.

Madrid, J. F.; Leis, O.; Díaz-Flores, L.; Sáez, F. \& Hernández, F. Lectin-gold localization of fucose residues in human gastric mucosa. J. Histochem. Cytochem., 46(11):131120, 1998.

Mayer, W. \& Tsukise, A. Lectin histochemistry of snout skin and foot bads in the wolf and domesticated dog. Ann. Anat., 6:177(1):39-49, 1995.

Monteruil, J. Primary structure of glycoprotein glycans: Basis for molecular biology of glycoprotein. $A d v$. Carbohydr. Chem. Biochem., 37:157-223, 1980.

Pedini, V.; Dall'Aglio, C.; Parillo, F. \& Scocco, P. Glycoconjugate distribution in gastric fundic mucosa of Umbrina cirrosa L. revealed by lectin histochemistry. $J$. Fish. Biology, 66(1):222-9, 2005.

Rios-Martin, J.; Diaz-Cano, S. \& Rivera-Hueto, F. Ultrastructural distribution of lectin-binding sites on gastric superficial mucus-secreting epithelial cells. The role of Golgi apparatus in the initial glycosylation. Histochem., 99(2):181-9, 1993.

Rhodes, M. \& Milton, J. Lectin methods and protocols. New Jersey, Humana Press, 1998.

Schulte, B. \& Spices S. Light microscopic study of terminal galactose and $\mathrm{N}$-acetylgalactosamine residues in rodent complex carbohydrates with galactose oxidaseschiff sequence and peanut lectin horseraddish peroxidase conjugates. J. Histochem. Cytochem., 31(1):19-24, 1983.

Schumacher, U.; Duku, M.; Katoh, M.; Jorns, J. \& Krause, W. L. Histochemical similarities of mucins produced by Brunner's glands and pyloric glands: A comparative study. Anat. Rec. a Discov. Mol. Cell Evol. Biol., 278(2):540-50, 2004.

Spicer, S. S.; Katsuyama, T. \& Sannes, P. L. Ultrastructural carbohydrate chemistry of gastric epithelium. Histochem. J., 10(3):309-31, 1978. 
FAYED, M. H.; ELNASHARTY, M. \& SHOAIB, M. Localization of sugar residues in the stomach of three species of monkeys (Tupaiidae glis, Nycticebus cocang and Callithrix jacchus) by lectin histochemistry. Int. J. Morphol., 28(I):111-120, 2010.

Stoward, P. J.; Spicer, S. S. \& Miller, R. L. Histochemical reactivity of peanut lectin-horseradish peroxidase conjugate. J. Histochem. Cytochem., 28(9):979-90, 1980.

Suzuki, S.; Tsuyama, S. \& Murata, F. Post-embedding staining of rat gastric mucous cells with lectins. Histochem., 73(4):563-75, 1982.

Tatematsu, M.; Katsuyama, T.; Mutai, M.; Asakawa, E. \& Ito, N. Pyloric gland phenotypic expression of gastric cancers developing in the rat fundic glandular stomach. Carcinogenesis, 10:1033-9, 1989.

Vandeheede, J. R.; Ahmed, A. I. \& Feeny, R. E. Structure and role of carbohydrate in freezing point- depressing glycoprotein from an Antarctic fish. J. Biol. Chem., 247(24):7885-9, 1972.

Wang, W. H. Observations on aggregated lymphoid nodules in the cardiac glandular areas of the Bactrian camel (Camelus bactrianus). Vet. J., 166(2):205-9, 2003.

Watanabe, M.; Muramatsu, T.; Shirane, H. \& Ugai K. Discrete distribution of binding sites for Dolichos biflorus agglutinin (DBA) and Peanut agglutinin (PNA) in mouse organ tissue. J. Histochem. Cytochem., 29(7):779-89, 1981.

Yang, D.; Karsamo, H.; Miyauchi, M.; Tsuyama, S. \& Murata, F. Ontogeny of sulphated glycocongujate producing cells in the rat fundic glands. Histochem. J., 28(1):33-43, 1996.
Correspondence to: Dr. Masoud Hassan Fayed Department of Anatomy Faculty of veterinary Medicine Kafer EL-Sheikh University Kafer EL-Sheikh City 33516 Kafer EL-Sheikh Governorates EGYPT

Telephone: +20473231607 $+20472313909$

Fax: $\quad+20473231311$

Email: masoudfayed@yahoo.com

Received: 05-11-2009

Accepted: 12-01-2010 